\title{
Levonorgestrel intrauterine releasing system: long term health impact
}

\author{
Urvashi Miglani*, Pushpa Singh
}

Department of Obstetrics \& Gynecology, PGIMER and Dr. R.M.L Hospital, New Delhi, India

Received: 12 April 2015

Accepted: 09 May 2015

\section{*Correspondence:}

Dr. Urvashi Miglani,

E-mail: urvashim513@gmail.com

Copyright: $\odot$ the author(s), publisher and licensee Medip Academy. This is an open-access article distributed under the terms of the Creative Commons Attribution Non-Commercial License, which permits unrestricted non-commercial use, distribution, and reproduction in any medium, provided the original work is properly cited.

\begin{abstract}
Background: Menorrhagia, menstrual blood loss of more than $80 \mathrm{ml}$ is a common health problem affecting 5-30\% of women in India and accounts for $8 \%$ loss of economic wages annually. This study was conducted in PGIMER and Dr. RML Hospital New Delhi to evaluate the efficacy, acceptability and safety profile of LNG IUS (a non-invasive modality) in a variety of gynaecological disorders with associated menorrhagia.

Methods: This was a noncomparative longitudinal observational study conducted in PGIMER and Dr RML Hospital New Delhi from June 2009 to September 2013.All patients with menorrhagia with or without dysmenorrhoea were screened and in suitable cases, LNG IUS was inserted in the postmenstrual phase after counselling and informed consent. Menstrual pattern, mean bleeding days, hemoglobin and satisfaction level was noted before insertion, 6 months, 1 year and 2 years post insertion.

Results: 30 patients were recruited in the study over the first 2 years. $66.66 \%$ (20) had associated medical co morbidities. LNG IUS was spontaneously expelled in $2(6.66 \%)$ and 3 subjects $(10 \%)$ needed a hysterectomy due to persistent bleeding. The remaining 25 subjects continued with the device and these subjects had a significant decrease in mean bleeding days with associated significant rise in hemoglobin levels over 2 years.

Conclusions: LNG-IUS is an underused useful device for several gynecological disorders and is a boon especially for those with medical comorbidities and should be offered to all suitable subjects.
\end{abstract}

Keywords: LNG IUS, Heavy menstrual bleeding, Fibroids, Anemia

\section{INTRODUCTION}

Menorrhagia, menstrual blood loss of more than $80 \mathrm{ml}$ is a common health problem affecting $5-30 \%$ of women in India and accounts for $8 \%$ loss of economic wages annually. ${ }^{1}$ There are a multitude of medical and surgical treatments available for this disorder including prostaglandin synthetase inhibitors, antifibrinolytic agents, oral contraceptive pills, endometrial ablation and hysterectomy but each one is tagged with few disadvantages. Traditional medical treatments for menorrhagia have been only temporarily effective (20 to $50 \%$ reduction in blood loss), if at all, and most patients refuse to be subjected to the associated side effects and repetitive nature of the treatment. ${ }^{2}$ On the other end of the spectrum are the surgical options which are generally incompatible with preservation of fertility and have a potentially avoidable morbidity, or even mortality and high cost. ${ }^{3}$

In this scenario, the levonorgestrel-releasing intrauterine system (LNG-IUS) has emerged in recent years as a valuable minimally invasive alternative to the classical medical and surgical methods and in comparison with these treatment modalities has shown to outperform. This study was conducted in PGIMER and Dr. RML Hospital New Delhi to evaluate the efficacy, acceptability and 
safety profile of LNG IUS in a variety of gynaecological disorders associated with menorrhagia.

\section{METHODS}

This was a noncomparative longitudinal observational study conducted in PGIMER and Dr. RML Hospital New Delhi from June 2009 to September 2013. All patients with menorrhagia with or without dysmenorrhoea were screened and suitable cases were recruited for the study after excluding malignancy, active liver disease, irregular uterine cavity and active pelvic inflammatory disease. LNG IUS was inserted in the postmenstrual phase after counselling and informed consent. The strict insertion technique for the device was adhered to so as to ensure proper fundal placement. The preinsertion counselling was done to sensitize the subjects to the side effects, failure rates and the need to take oral hormone therapy for first few months. Ultrasonography was done to confirm placement of IUS.

Menstrual pattern, mean bleeding days and hemoglobin was noted before insertion, 6 months, 1 year and 2 years post insertion. Sonographic fibroid volume was calculated pre and 2 years post insertion. Lipid Profile was done pre and 2 years post insertion. Patients rated dysmennorrhoea on a scale from 0 to 10 pre and post insertion ( 0 indicating no dysmennorrhoea and 10 indicating intolerable pain). The impact of menstrual pattern and side effects on their general well-being was rated as very satisfying, moderately satisfying, and dissatisfying. Statistical Analysis was done using the paired T test and Wilcoxon Signed Ranks test.

\section{RESULTS}

30 patients were recruited in the study over the first 2 years. Most of the women were in the age group of 36 to 45 years with a mean age of 40.32 years (Table 1 ). 12 patients were diagnosed to have fibroid uterus, 8 had idiopathic menorrhagia, 6 had adenomyosis and endometrial hyperplasia was diagnosed in 4 subjects (Figure 1). 66.66\% (20) had associated medical diseases. During the first 6 months, LNG IUS was spontaneously expelled in $2(6.66 \%)$ and 3 subjects (10\%) needed a hysterectomy due to persistent bleeding. The remaining 25 subjects continued with the device and these subjects had a significant decrease in mean bleeding days with associated significant rise in hemoglobin levels over 2 years (Table 2 and 3 ).

$40 \%$ of the patients were amenorrhoeic by 1 year and $64 \%$ had attained amenorrhoea by 2 years. In the subjects with fibroid, there was a significant decrease in the mean bleeding days and mean fibroid volume (Table 4). The subjects with fibroid, in whom LNG IUS was successful, had significantly lower fibroid volume than the subjects in whom mirena failed (Table 5). There was a decrease in mean dysmenorrhoea score from 8 at baseline to 2 at 6 months and 1.5 at 2 years.
The subjects' experienced minor side effects viz weight gain, $(8 \%)$, pelvic infection (4\%), hormonal effects $(8 \%)$ and expulsion $(6.66 \%)$ but the most troublesome side effect was irregular spotting $(76 \%)$. However no ovarian cysts were reported in any of the subjects.

The mean cholesterol, LDL (low density lipoprotein), and triglyceride levels also decreased significantly over two years (Table 6).

Table 1: Demographic profile.

\begin{tabular}{|llll|}
\hline N & $\begin{array}{l}\text { Age } \\
\text { (years) }\end{array}$ & $\begin{array}{l}\text { Parity } \\
\text { (number) }\end{array}$ & $\begin{array}{l}\text { Duration } \\
\text { of bleeding } \\
\text { (years) }\end{array}$ \\
\hline Minimum & 25 & 25 & 25 \\
\hline Maximum & 29 & 2 & 0.5 \\
\hline Mean & 50 & 3 & 15.0 \\
\hline Std. Deviation & 40.32 & 2.20 & 3.580 \\
\hline Median & 5.406 & 0.408 & 2.8199 \\
\hline Std. Error of Mean & 40.00 & 2.00 & 3.000 \\
\hline
\end{tabular}

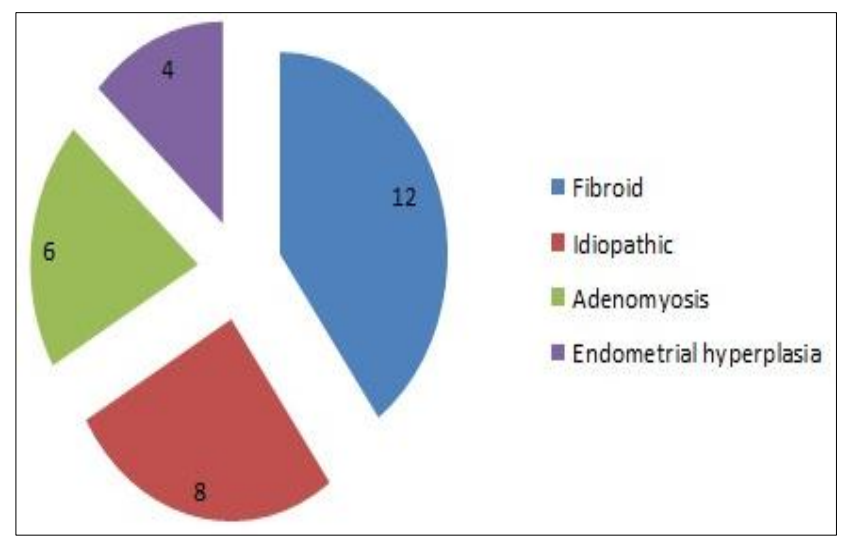

Figure 1: Patient distribution with regards to underlying pathology $(\mathrm{N}=30)$.

Table 2: Mean bleeding days.

\begin{tabular}{|lllll|}
\hline & $\begin{array}{l}\text { Mean } \\
\text { bleeding } \\
\text { days } \\
\text { (days) } \\
\text { Base line }\end{array}$ & $\begin{array}{l}\text { Mean } \\
\text { bleeding } \\
\text { days } \\
\text { (days) } \\
\mathbf{6} \text { months }\end{array}$ & $\begin{array}{l}\text { Mean } \\
\text { bleeding } \\
\text { days } \\
\text { days) } \\
12 \text { months }\end{array}$ & $\begin{array}{l}\text { Mean } \\
\text { bleedin } \\
\text { g days } \\
\text { (days) } \\
\text { 2 year }\end{array}$ \\
\hline sN & 25 & 25 & 25 & 25 \\
\hline Minimum & 5 & 2 & 0 & 0 \\
\hline Maximum & 10 & 4 & 3 & 3 \\
\hline Mean & 6.86 & 2.96 & 1.28 & 0.64 \\
\hline $\begin{array}{l}\text { Std. } \\
\text { Deviation }\end{array}$ & 1.271 & 0.406 & 1.200 & 1.036 \\
\hline Median & 6.50 & 3.00 & 1.50 & 0.00 \\
\hline $\begin{array}{l}\text { Std. Error } \\
\text { of Mean }\end{array}$ & 0.254 & 0.081 & 0.240 & 0.207 \\
\hline P value & & 0.000 & 0.000 & 0.000 \\
\hline
\end{tabular}


Table 3: Mean hemoglobin levels.

\begin{tabular}{|c|c|c|c|c|}
\hline & $\begin{array}{l}\text { Hemoglobin } \\
\text { levels } \\
\text { (gm \%) } \\
\text { base line }\end{array}$ & $\begin{array}{l}\text { Hemoglobin } \\
\text { levels } \\
\text { (gm\%) } \\
6 \text { months }\end{array}$ & $\begin{array}{l}\text { Hemoglobin } \\
\text { levels } \\
\text { (gm\%) } \\
12 \text { months }\end{array}$ & $\begin{array}{l}\text { Hemoglobin } \\
\text { levels } \\
\text { (gm \%) } \\
2 \text { year }\end{array}$ \\
\hline $\mathrm{N}$ & 25 & 25 & 25 & 25 \\
\hline Minimum & 7.4 & 9.0 & 10.0 & 11.0 \\
\hline Maximum & 10.5 & 12.0 & 12.0 & 14.0 \\
\hline Mean & 9.072 & 10.340 & 11.36 & 11.56 \\
\hline Std. Deviation & 0.835 & 0.694 & 0.460 & 0.680 \\
\hline Median & 9.200 & 10.500 & 11.20 & 11.50 \\
\hline Std. Error of Mean & 0.167 & 0.139 & 0.092 & 0.13 \\
\hline $\mathrm{P}$ value & & 0.000 & 0.000 & 0.000 \\
\hline
\end{tabular}

Table 4: Mean fibroid volume.

\begin{tabular}{|c|c|c|}
\hline & $\begin{array}{l}\text { Fibroid volume if } \\
\text { applicable (cc) baseline }\end{array}$ & $\begin{array}{l}\text { Fibroid volume if } \\
\text { applicable (cc) } 2 \text { years }\end{array}$ \\
\hline $\mathrm{N}$ & 9 & 9 \\
\hline Minimum & 2.569 & 0.523 \\
\hline Maximum & 16.585 & 5.850 \\
\hline Mean & 7.279 & 2.608 \\
\hline Std. Deviation & 4.389 & 2.376 \\
\hline Median & 5.568 & 1.046 \\
\hline Std. Error of Mean & 1.463 & 0.792 \\
\hline P value (Wilcoxon Signed ranked test) & & 0.000 \\
\hline
\end{tabular}

Table 5: Mean fibroid volume in subjects with successful and failed mirena.

\begin{tabular}{|lllllllll|} 
Mirena & N & Min & Maximum & Mean & $\begin{array}{l}\text { Std. } \\
\text { Deviation }\end{array}$ & Median & $\begin{array}{l}\text { Std. Error } \\
\text { of Mean }\end{array}$ & P value \\
Failed & 3 & 26.523 & 65.372 & 48.07 & 19.770 & 5.232 & 11.414 & \\
\hline Successful & 9 & 2.569 & 16.585 & 7.279 & 4.389 & 5.568 & 1.463 & \\
\hline Total & 12 & 2.569 & 65.372 & 1.747 & 20.626 & 9.414 & 5.954 & 0.011 \\
\hline
\end{tabular}

Table 6: Lipid profile levels.

\begin{tabular}{|c|c|c|c|c|c|c|}
\hline & $\begin{array}{l}\text { Total } \\
\text { cholesterol } \\
\text { (mg\%) } \\
\text { base line }\end{array}$ & $\begin{array}{l}\text { Total } \\
\text { cholesterol } \\
\text { (mg\%) } \\
2 \text { year }\end{array}$ & $\begin{array}{l}\text { LDL } \\
(\mathrm{mg} \%) \\
\text { base line }\end{array}$ & $\begin{array}{l}\mathrm{LDL} \\
(\mathrm{mg} \%) \\
2 \text { years }\end{array}$ & $\begin{array}{l}\text { Triglyceride } \\
\text { (mg\%) } \\
\text { base line }\end{array}$ & $\begin{array}{l}\text { Triglyceride } \\
(\mathrm{mg} \%) \\
2 \text { years }\end{array}$ \\
\hline $\mathrm{N}$ & 25 & 25 & 25 & 25 & 25 & 25 \\
\hline Minimum & 132 & 118 & 65 & 67 & 45 & 31 \\
\hline Maximum & 206 & 204 & 150 & 146 & 126 & 110 \\
\hline Mean & 157.48 & 154.32 & 93.80 & 90.90 & 76.20 & 72.28 \\
\hline Std. Deviation & 18.744 & 19.610 & 17.975 & 17.414 & 21.854 & 20.326 \\
\hline Median & 156.00 & 156.00 & 98.00 & 92.00 & 77.00 & 72.00 \\
\hline Std. Error of Mean & 3.749 & 3.922 & 3.595 & 3.483 & 4.371 & 4.065 \\
\hline $\mathrm{P}$ value & & 0.017 & & 0.001 & & 0.031 \\
\hline
\end{tabular}

\section{DISCUSSION}

Progesterone is a key hormone in regulating the female reproductive system interacting at the level of the hypothalamus, ovary, uterus and breast. Progestins are available for oral, injectable, implantable as well as intrauterine delivery. ${ }^{4}$ Intrauterine delivery of progestin is an effective way to administer local treatment and bypass 
the systemic side effects. In addition to providing highly effective contraception, intrauterine progestin delivery is safe and effective in the management of menorrhagia, dysmenorrhoea, uterine myomata and endometrial proliferation. The levonorgestrel-releasing intrauterine system (LNG IUS) is marketed under the name Mirena (Bayer Schering Pharma, Berlin, Germany). The LNGIUS is a T-shaped device composed of a cylinder containing $52 \mathrm{mg}$ of LNG covered by a rate-controlling membrane which serves to regulate the rate of hormonal release. Initially, $20 \mu \mathrm{g}$ of levonorgestrel is released every 24 hours from this polymer cylinder. This decreases to 11 $\mu \mathrm{g}$ every 24 hours by the end of five years, with an average release rate of $14 \mu \mathrm{g}$ per day over the life of the IUS. Levonorgestrel, a highly potent second generation progestin acts by thickening the cervical mucus and suppressing endometrial proliferation. ${ }^{5}$

The LNG IUS has been evaluated for its impact on menstrual blood loss and acceptability in patients of menorrhagia. One study comparing the LNG-IUS and norethisterone showed that the LNG-IUS reduced menstrual blood flow by $94 \%$ and norethisterone by $87 \%$. However, after three cycles of treatment, $76 \%$ of the LNG-IUS group wished to continue the treatment, compared with only $22 \%$ of the medical therapy group. ${ }^{6}$ Based on the meta-analysis of six randomized clinical trials, it was concluded that the levonorgestrel intrauterine system appears to have similar therapeutic effects to that of endometrial ablation in heavy menstrual bleeding up to 2 years after treatment. ${ }^{7}$

In addition, the LNG-IUS has been used in numerous studies to compare outcomes with hysterectomy for treatment of menorrhagia. A randomized controlled trial of 236 women assigned either to LNG-IUS or hysterectomy showed that after one year the two treatments were associated with equal improvements in health status, quality of life, and psychosocial well-being, but the IUS was more cost-effective. ${ }^{8}$ Cochrane review of the subject concluded that use of the LNG-IUS results in a significant decrease in the amount of menstrual bleeding, and that it is more cost-effective as a treatment for menorrhagia than hysterectomy both at one and five years. ${ }^{9}$ As has been reiterated in the present study also, the LNG-IUS is a satisfactory, effective, and economical alternative to medical and surgical treatment of menorrhagia

The enigmatic disorder of adenomyosis has historically been diagnosed and treated with hysterectomy. However, diagnosis has recently become possible using a combination of transvaginal ultrasound and magnetic resonance imaging. As a result, there has been a concerted effort on the part of gynaecologists to find an effective, but less invasive treatment for the disorder. In light of the side effects of medical treatment and the ineffectiveness of ablation, the LNG-IUS is becoming an increasingly attractive option for treatment of adenomyosis. It is hypothesized to work on adenomyosis in two ways. First it causes decidualization and atrophy of the endometrium, therefore decreasing the amount of menstrual flow. Secondly, the levonorgestrel down regulates estrogen receptors in glandular and stromal endometrial tissues. This likely prevents further estrogen stimulation of the adenomyosis foci within the myometrium, causing them to atrophy and shrink. This may lead to decreased menstrual flow by allowing the myometrium to contract better, limiting the blood loss during menses, and also accounts for decreased size of the uterus. ${ }^{9}$ The present study demonstrated a beneficial effect of LNG IUS on the menstrual bleeding in patients with adenomyosis. The other studies conducted on the subject also show that LNG IUS decreases the menstrual flow, dysmenorrhoea score, mean uterine volume and uterine artery blood flow. ${ }^{10,11}$ However, as with uterine size, the pain scores and blood flow increased again after 36 months, though they were still significantly less than the initial values. Though the exact cause for this phenomenon is unknown, it is hypothesized that it could be attributed to the decreased amount of hormone released by the LNG-IUS daily overtime. ${ }^{11}$ Regardless, the LNG-IUS does appear to be an effective treatment for adenomyosis with improvement in pain and bleeding scores over two years. Further studies will need to address whether replacing the LNG-IUS after 2-3 years will keep the pain and bleeding scores from increasing again over time.

Recently, LNGIUS is being tried in subjects with fibroids with variable results. In the few small prospective studies on the subject, LNGIUS decreased menstrual blood loss by $54-69 \%$ at 12 months. ${ }^{13-15}$ The present study also highlights the potential role of mirena in subjects with small intramural fibroids. However failure in subjects with larger myomas stresses on the need to study the approximate size of fibroids till which this device will be effective.

As LNG-IUS is a boon for subjects with menorrhagia and co morbid medical conditions, it seems logical to have an insight into the possible influence of LNG-IUS on the lipid profile of the subjects. Though the data about this is scarce, the results of the present study are in accord with the only recent study on the subject which shows a positive impact. ${ }^{16}$

Despite being a local source of progestogen, there is a growing evidence of elevated serum and tissue levels of levonorgestrel and high dissatisfaction and discontinuation rates especially among subjects using the LNG-IUS for its noncontraceptive benefits. The discontinuation rates increased with the duration of use escalating from $30-32 \%$ after 1 year to $50-60 \%$ after 5 years of use. ${ }^{17,18}$ The common reasons for early removal were unscheduled bleeding and progestogenic adverse effects. This has also been emphasized in the guidelines of The National Institute for Health and Clinical Excellence (NICE), United Kingdom which recommend that healthcare professionals should be aware that up to $60 \%$ of women discontinue using mirena within 5 years 
due to unscheduled bleeding, pain and/or systemic progestogenic adverse effects. ${ }^{19}$

In contrast, the present study showed high satisfaction and continuation rates which were probably due to the strict inclusion criteria and the extensive pre and post insertion counselling sessions which sometimes also included talks with fellow patients with LNG IUS in situ. Although the importance of counselling has always been stressed upon with LNG-IUS use, a recent large study among 17,914 LNG-IUS users has objectively analysed the impact and quality of prior information about adverse effects on user satisfaction. ${ }^{20}$ They concluded that user satisfaction was strongly associated with information given at the time of insertion of the LNG-IUS with the well informed subjects having significantly higher continuation rates.

\section{Emerging indications}

- $\quad$ LNG-IUS has recently been tried in premenopausal women with early endometrial carcinoma with $63 \%$ response rate. ${ }^{21}$ This seems to be a realistic treatment option in selected patients in the closely supervised environment of a specialised gynecology oncology unit.

- LNG-IUS was used to treat menstrual problems in adolescents with a range of medical problems or with severe learning disability with significant therapeutic benefit. $^{22}$ The additional contraceptive protection is an added bonus in such subjects where contraception or vulnerability is a long term concern.

\section{CONCLUSIONS}

- We LNG-IUS is an underused useful device for several gynecological disorders and should be offered to all suitable subjects

- Malignancy, pelvic inflammatory disease and irregular uterine cavity should be ruled out before inserting LNG-IUS.

- Strict Insertion technique for the device should be adhered to.

- $\quad$ Pre and post insertion counselling regarding possible adverse effects is vital for the success of this device.

- Randomised controlled trials are required to evaluate its long term effectiveness in adenomyosis and leiomyomas.

Funding: No funding sources Conflict of interest: None declared

Ethical approval: Not required

\section{REFERENCES}

1. Harlow SD, Campbell O. MR. Epidemiology of menstrual disorders in developing countries: a systematic review. BJOG. 2004;111:6-16.

2. Milsom I. The levonorgestrel-releasing intrauterine system as an alternative to hysterectomy in perimenopausal women. Contraception. 2007;75(6 Suppl):S152-4.

3. Kaunitz AM, Meredith S, Inki P, Kubba A, SanchezRamos L. Levonorgestrel-releasing intrauterine system and endometrial ablation in heavy menstrual bleeding: a systematic review and meta-analysis. Obstet Gynecol. 2009 May;113(5):1104-16.

4. Pintiaux A, Chabbert Buffet N, Foidart JM. Gynecological uses of a new class of steroids: the selective progesterone receptor modulators. Gynecol Endocrinol. 2009;25:67-73.

5. Berlex Pharmaceuticals. Mirena ${ }^{\circledR}$ Physician Information, July 2008. Available at: http://berlex.bayerhealthcare.com/html/products/pi/ Mirena_PI.pdf.2. Accessed 24 June 2009.

6. Irvine GA, Campbell-Brown MB, Lumsden MA, Heikkilä A, Walker JJ, Cameron IT. Randomised comparative trial of the levonorgestrel intrauterine system and norethisterone for treatment of idiopathic menorrhagia. $\mathrm{Br} \quad \mathrm{J}$ Obstet Gynaecol. 1998;105(6):592-8.

7. Andrew M, Susanna M, Pirjo I. Ali K, Luis S. Levonorgestrel releasing Intrauterine system and Endometrial ablation in heavy menstrual bleeding :a systematic review and meta-analysis. Obstet Gynecol. 2009;113:1104-16.

8. Hurskainen R, Teperi J, Rissanen P, Aalto AM, Grenman S, Kivelä A, et al. Quality of life and costeffectiveness of levonorgestrel-releasing intrauterine system versus hysterectomy for treatment of menorrhagia: a randomised trial. Lancet. 2001;357(9252):273-7.

9. Lethaby A, Cooke I, Rees MC. Progesterone or progestogen-releasing intrauterine systems for heavy menstrual bleeding. Cochrane Database Syst Rev. 2005;4:CD002126.

10. Fong Y, Singh K. Medical treatment of a grossly enlarged adenomyotic uterus with the levonorgestrelreleasing intrauterine system. Contraception. 1999;60:173-5.

11. Cho S, Nam A, Kim H, Chay D, Park K, Cho DJ, et al. Clinical effects of the levonorgestrel releasing intrauterine device in patients with adenomosis. Am J Obstet Gynecol. 2008;198:373.e1-7.

12. Sheng J, Zhang WY, Zhang JP, Lu D. The LNG-IUS study on adenomyosis: a 3-year follow-up study on the efficacy and side effects of the use of levonorgestrel intrauterine system for the treatment of dysmenorrhea associated with adenomyosis Contraception. 2009;79:189-93.

13. Magalhães J, Aldrighi JM, de Lima GR. Uterine volume and menstrual patterns in users of the levonorgestrel-releasing intrauterine system with 
idiopathic menorrhagia or menorrhagia due to leiomyomas. Contraception. 2007;75(3):193-8.

14. Mercorio F, De Simone R, Di Spiezio Sardo A, Cerrota G, Bifulco G, Vanacore F, et al. The effect of a levonorgestrel-releasing intrauterine device in the treatment of myoma-related menorrhagia. Contraception. 2003;67(4) :277-80.

15. Tasci Y, Caglar GS, Kayikcioglu F Cengiz H, Yagci B, Gunes M. Treatment of menorrhagia with the levonorgestrel releasing intrauterine system: effects on ovarian function and uterus. Arch Gynecol Obstet. 2009;280:39-42.

16. Ferreira RA, Vieira CS, Rosa-E-Silva JC, Rosa-eSilva AC, Nogueira AA, Ferriani RA. Effects of the levonorgestrel-releasing intrauterine system on cardiovascular risk markers in patients with endometriosis: a comparative study with the GnRH analogue. Contraception. 2010-02;81(2):117-22.

17. Lockhat FB, Emembolu JE, Konje JC. Serum and peritoneal fluid levels of levonorgestrel in women with endometriosis who were treated with an intrauterine contraceptive device containing levonorgestrel. Fertil Steril. 2005;83:398-404.
18. Daud S, Ewies AA. Levonorgestrel-releasing intrauterine system: why do some women dislike it? Gynecol Endocrinol. 2008;24:686-90.

19. National Institute for Health and Clinical Excellence. Heavy menstrual bleeding. In: NIHCE, eds. NICE Clinical Guidelines 44. India: NISCH; 2007.

20. Backman T, Huhtala S, Luoto R, Tuominen J, Rauramo I, Koskenvuo M. Advance information improves user satisfaction with the levonorgestrel intrauterine system. Obstet Gynecol. 2002;99:60813.

21. Cade TJ, Quinn MA, Rome RM, Neesham D. Progestogen treatment options for early endometrial cancer. BJOG. 2010 Jun;117(7):879-84.

22. Pillai M, O'Brien K, Hill E. The levonorgestrel intrauterine system (Mirena) for the treatment of menstrual problems in adolescents with medical disorders, or physical or learning disabilities. BJOG 2010;117(2):216-21.

DOI: $10.18203 / 2320-1770.1 j \mathrm{rcog} 20150094$

Cite this article as: Miglani U, Singh P. Levonorgestrel intrauterine releasing system: long term health impact. Int J Reprod Contracept Obstet Gynecol 2015;4:795-800. 